\title{
O julgamento no Supremo do aborto de anencéfalo-ADPF 54: uma etnografia da religião no espaço público
}

The Supreme Court trial of abortion of anencephalous

- ADPF 54: an ethnography of religion in public space

\author{
Naara Luna* \\ * Universidade Federal Rural do Rio de Janeiro - Seropédica, RJ, Brasil \\ naaraluna2015@gmail.com
}




\title{
Resumo
}

Considerando a religião no espaço público, o aborto é dos temas que mais mobilizam o engajamento de atores religiosos que tentam influir no debate. $\mathrm{O}$ artigo analisa $\mathrm{o}$ julgamento da Arguição de Descumprimento de Preceito Fundamental 54 (ADPF 54) realizado no Supremo Tribunal Federal em 11 e 12 de abril de 2012. Realizou-se observação etnográfica de uma vigília realizada em frente ao STF na véspera do julgamento, um ato religioso antes da sessão, os rituais que cercaram o julgamento desde a entrada no STF, até os procedimentos processuais, além do conteúdo dos votos dos ministros e as manifestações no plenário. Alguns personagens emblemáticos circularam no tribunal e no entorno e se tornaram figuras públicas simbólicas naquela causa, caso da anencefálica Marcela de Jesus. O trabalho reflete sobre a dimensão do sagrado presente em várias instâncias e a mobilização de religiosos. Constatou-se diversidade religiosa com presença de católicos, espíritas e evangélicos.

Palavras-chave: aborto; ADPF 54; Supremo Tribunal Federal; religião no espaço público.

\begin{abstract}
Regarding religion in public space, abortion is one of the matters that most engage religious actor trying to influence the debate. The article analyses the trial of Accusation of Non-Compliance with a Fundamental Precept (ADPF 54) happened in Supreme Federal Court on April 11th and 12th 2012. The author did ethnographic observation of a vigil in front of Supreme Court on the eve of the trial, a religious service before the session, the rituals that involved the trial since the entrance in the building, up to processual procedures, besides the content of votes of the ministers and the reactions of the plenary. Some emblematic characters circulate in the court and around that became symbolic public figures in that cause, such as the anencephalic baby Marcela de Jesus. The article discusses the sacred dimension in various instances and the mobilization of religious actors. Religious diversity was observed with presence of Catholics, Kardecist Spiritist and Evangelicals.
\end{abstract}

Keywords: abortion; ADPF 54; Supreme Court (Brazil); religion in public space. 


\section{Introdução ${ }^{1}$}

No debate sobre religião no espaço público, está implícita a teoria da secularização, "processo pelo qual setores da sociedade e da cultura são subtraídos à dominação das instituições e símbolos religiosos" (Berger, 1985), o que na modernidade ocidental implicaria entre outros aspectos, em termos socioestruturais, a separação de Igreja e Estado, em termos de cultura e símbolos, o declínio dos conteúdos religiosos e a ascensão da ciência, e a secularização das consciências, ao se encarar o mundo sem interpretações religiosas. Se forças secularizantes se expandiram com a ocidentalização e a modernização, o processo atinge a sociedade de formas heterogêneas, com segmentos menos secularizados nas margens da sociedade industrial. Berger (2001) vai revisitar o tema posteriormente afirmando que a própria modernidade cria movimentos de resistência e contrassecularização, de modo que a rejeição e a adaptação são duas estratégias para comunidades religiosas em um mundo que se considera secularizado. Movimentos tradicionalistas ou conservadores têm crescido e rejeitam o aggionarmento, à adaptação a valores modernos. Essa resistência é o cenário de atuação de diversos atores religiosos como na etnografia que motivou o presente artigo, observando uma controvérsia pública, o debate sobre aborto, em um cenário específico com seus diversos atores.

Casanova (1994 apud Montero, 2016), em sua definição de religião pública, afirma que as religiões se "desprivatizaram" em dois sentidos, tornando-se objeto de atenção de vários públicos e "colocando-se na esfera pública como forças de contestação moral e política" (Casanova, 1994 apud Montero, 2016, p. 143). É desse segundo aspecto que vai tratar o presente artigo. Considerando que, na década de 1980, tradições religiosas se revitalizaram e assumiram papéis públicos, Casanova (1994, p. 6) cria o neologismo "desprivatização" para questionar as teorias de secularização que não apenas supuseram, mas prescreveram a privatização da religião no mundo moderno. Embora o autor concorde com a teoria no sentido de que houve diferenciação e emancipação

1 O artigo integra projeto de pesquisa financiado com bolsa de produtividade nível 2 do CNPq e se baseia na comunicação apresentada no Grupo de Trabalho 14 - Direitos humanos, sexualidade e cultura, durante a IV Reunião Equatorial de Antropologia e XIII Reunião de Antropólogos do Norte e Nordeste, realizada de 4 a 7 de agosto de 2013 em Fortaleza. 
de esferas seculares das instituições religiosas, Casanova usa o termo desprivatização para significar novos movimentos históricos que parecem indicar uma reversão de tendências seculares. No mundo todo, religiões estão entrando na arena pública e na contestação política não apenas para defender seus territórios tradicionais, mas para participar das lutas que definem a separação entre as esferas pública e privada, entre legalidade e moralidade, entre família, sociedade civil e o Estado. Considero estes últimos tópicos, dentre outros citados por Casanova, como os mais relevantes para o presente artigo. Mais adiante, Casanova (1994, p. 57-58) afirma que, da perspectiva normativa da modernidade, a religião pode entrar na esfera pública e assumir uma forma pública somente se aceita o direito inviolável à privacidade e o princípio de liberdade de consciência. Assim a desprivatização da religião poderia ser justificada em três instâncias: 1) quando entra na esfera pública para proteger não apenas a própria liberdade de religião, mas todas as liberdades e direitos modernos; 2) quando questiona e contesta a autonomia legítima das esferas seculares e sua organização que não leva em conta questões morais e éticas extrínsecas; 3) para proteger o tradicional mundo da vida da penetração administrativa ou jurídica do Estado, abrindo questões sobre a formação de normas e da vontade para a reflexão coletiva e pública acerca da ética moderna discursiva. Este último caso se aplicaria ao debate sobre o aborto, segundo o próprio Casanova, objeto da etnografia aqui apresentada.

Quando se considera a religião no espaço público, o aborto é dos temas que mais mobilizam o engajamento de atores religiosos que tentam influir no debate. O tema do aborto está no vértice da discussão sobre direitos humanos tanto com respeito a direitos atribuídos ao feto, como o direito à vida, como no tocante à esfera de decisão da mulher. Nesse contexto, está em debate a condição de pessoa desses entes fundamentada na configuração individualista de valores da cosmologia ocidental moderna, mas integram o pano de fundo do debate as dimensões holistas relacionadas ao caráter sagrado da vida e do ser humano (Dumont, 1997). No caso da anencefalia, a discussão se estende para aspectos como viabilidade, racionalidade e sofrimento dos envolvidos. Este artigo faz uma descrição etnográfica e análise do julgamento da Arguição de Descumprimento de Preceito Fundamental 54 (ADPF 54) realizado no Supremo Tribunal Federal nos dias 11 e 12 de abril de 2012. Foram observados uma vigília realizada em frente ao STF na véspera do julgamento, um ato religioso antes 
da sessão, os rituais que cercaram o julgamento desde a entrada no STF, até os procedimentos processuais, além das exposições orais dos votos dos ministros e as manifestações no plenário. ${ }^{2}$ Circularam no tribunal e no seu entorno alguns personagens que se tornaram figuras simbólicas naquela causa e outros foram continuamente mencionados, caso da menina Marcela de Jesus, diagnosticada com anencefalia. ${ }^{3}$ Esta etnografia pergunta como estratégias de ritualização "produzem sentidos coletivos que especificam e constroem, ao mesmo tempo, um espaço, um público determinado e um repertório cívico urbano" (Montero; Brum; Quintanilha, 2016, p. 705). O trabalho pretende refletir primeiramente sobre a dimensão do sagrado presente em várias instâncias: o debate sobre o direito à vida, o recinto sacro do tribunal e seus vestais, a contraposição de indivíduos sagrados (o feto e a gestante) e a mobilização de religiosos. Constatou-se diversidade religiosa com presença de católicos e espíritas e um contingente mínimo de evangélicos, engajamento diferencial este que merecerá exame à parte.

Em 17 de junho de 2004, a Confederação Nacional de Trabalhadores da Saúde ajuizou a ADPF 54 perante o Supremo Tribunal Federal com o objetivo de assegurar às gestantes de anencéfalo o direito de se submeterem à antecipação terapêutica de parto e ao médico a possibilidade de realizá-la, se atestada a anomalia por profissional habilitado, sem a necessidade de apresentar a autorização prévia judicial. A ação descaracteriza a ilicitude penal dessa interrupção da gravidez, argumentando não se enquadrar nos artigos 124, 126, caput e 128, I e II do Código Penal, que tratam do aborto provocado pela gestante ou com seu consentimento, e do aborto não punível ${ }^{4}$ (Fernandes, 2007). Segundo a petição, defendida pelo advogado Luís Roberto Barroso, "antecipação terapêutica de parto de anencéfalo não é aborto", tese fundamentada na inviabilidade do feto. A aplicação desse conjunto normativo do Código Penal no caso da gestação de feto anencefálico violaria os preceitos constitucionais de dignidade

2 O relato foi construído praticamente todo com base em apontamentos de campo. As observações entre parênteses são explicações para facilitar a compreensão.

3 Marcela de Jesus foi diagnosticada ainda intraútero com anencefalia. Nascida em 20/09/2006, a bebê viveu um ano e oito meses e teve o diagnóstico questionado, sofrendo de uma anomalia mais rara que lhe permitiu sobrevida excepcional. Ver documentário Flores de Marcela (Luna, 2014).

4 Refere-se aos dois permissivos "quando não há outro meio de salvar a vida da gestante" (Brasil, 1940, art. 128, inciso I); "se a gravidez resulta de estupro" (Brasil, 1940, art. 128, inciso II). 
da pessoa humana, o princípio da legalidade, liberdade e autonomia da vontade e o direito à saúde (Brasil, 2004, p. 2-4). O Ministro Marco Aurélio Mello deferiu a medida liminar em $1^{\circ}$ de abril de 2004, contudo, em 20 de outubro de 2004, a liminar foi revogada por decisão do plenário do STF. Em 27 de maio de 2005, aprovou-se a admissibilidade da ADPF 54 (Fernandes, 2007). Após o resultado da Ação Direta de Inconstitucionalidade (ADI) 3510, que autorizou a extração de células-tronco embrionárias de embriões restantes de reprodução assistida, o relator Marco Aurélio Mello convocou uma audiência pública realizada em sessões nos dias 26 e 28 de agosto, e 4 e 16 de setembro de 2008 (Luna, 2015). O julgamento da ação será aqui analisado.

\section{A vigília}

Como parte da mobilização para influir no julgamento do STF, a Igreja Católica chamou (em nome do papa Bento XVI) para a "Vigília de oração pela vida nascente" em frente ao STF na véspera do julgamento às $18 \mathrm{~h}$ (Conferência Nacional dos Bispos do Brasil, 2012). Foi um momento em que "a exploração etnográfica das estratégias de ritualização" permite "evidenciar os padrões que conformam a fala pública da Igreja Católica" (Montero; Brum; Quintanilha, 2016, p. 726) em um evento que se pretendia ecumênico. Chego às 18h30. Há grades móveis em torno do prédio do Supremo Tribunal Federal que mantêm os manifestantes à grande distância. Apesar da escuridão, são visíveis faixas e pôsteres junto dessa grade. Uma faixa traz o dizer "eugenia não". Há um círculo de 80 pessoas, que chegou a 150, inclusive franciscanos e algumas freiras trajando hábito. Reconheço a vice-coordenadora espírita do Movimento Brasil sem Aborto, no Rio de Janeiro. Pessoas chegam, distribuindo e acendendo velas. Anuncia-se a presença do vice-presidente da Federação Espírita do Brasil, do presidente da Associação de Juristas Espíritas de Minas Gerais, da vice-presidente da Associação Médico-Espírita do Brasil. Vários tomam o microfone e se pronunciam: um visitou os gabinetes dos ministros do STF para entregar um memorial com reflexão jurídica e médica. Fala da importância do amor ao próximo no Brasil, começando pelo direito à vida. Uma manifestante conclama a defender a vida mais frágil, denunciando o aborto de anencéfalo como aborto eugênico, exemplificado na redução dos nascimentos de crianças com síndrome de Down. 
Um padre declara que os ministros são insensíveis aos argumentos médicos, antropológicos e jurídicos, acrescentando que só Deus os poderia demover.

Um jurista espírita alerta sobre o Brasil ser signatário de documentos internacionais que preservariam a vida desde a concepção. Ele defende o princípio da precaução lançando dúvidas sobre a inviabilidade do anencéfalo. Um exemplo da legislação brasileira protegendo a vida desde a concepção é previsão dos alimentos gravídicos (pensão para a gestante). Se o Ibama protege os ovos dos animais, os humanos devem ser protegidos.

Padre Pedro, um polonês da diocese de Luziânia (GO), relata a experiência da Polônia, quando o governo comunista legalizou o aborto em 1953. A igreja fez vigília e a lei foi revogada em 1993.

A cantora Elba Ramalho conta que teve um show pró-vida, sem cachê, cortado pelo Ministério da Cultura, por ser o governo favorável à legalização do aborto, e que foi criticada por feministas. Ela relata ter feito aborto e, confessando esse pecado, Nossa Senhora lhe disse para lutar pela vida. Cita o governador Sérgio Cabral, para quem "matar crianças" diminuiria o número de bandidos; ${ }^{5}$ Elba diz que $82 \%$ da população brasileira são contra o aborto (pesquisa do Vox Populi de 2010, citada por vários) e os ministros deveriam respeitar isso. No aborto, a mulher mata o próprio filho. A cantora canta o sucesso "Bate coração" e a "Oração de São Francisco", acompanhada pelos presentes.

Um católico leigo diz que os ministros deveriam ouvir o clamor do povo, comparando aborto com a morte das crianças inocentes por Herodes: uma mentalidade ateia, pagã, que não respeita a vida nem as tradições.

Os presentes cantam a oração de São Francisco e rezam o Pai-Nosso.

Dom Luiz Gonzaga Bergonzini, bispo de Guarulhos (SP), fala que o evento é de todos os cristãos, porque todos são batizados e seguem a Deus. Pede que Deus fortaleça todos os que lutam pela vida contra a morte.

É perceptível a preocupação de não incluir orações ou cânticos exclusivamente católicos. Por conta disso, se puxa a oração do Pai-Nosso várias vezes, repetição que não é usada entre evangélicos.

5 Em entrevista ao canal de notícias Glconcedida em 2007, o então governador Sergio Cabral defendeu a legalização do aborto como forma de combater a violência no Rio de Janeiro: "Interrupção da gravidez tem tudo a ver com a violência pública" (cf. Freire, 2007). 
O deputado Eros Biondini ${ }^{6}$ (PTB-MG) se anuncia e a seu companheiro de bancada católica, o deputado Givaldo Carimbão (PSB-AL). Biondini conta sobre seu pronunciamento no Congresso Nacional para que os deputados se posicionassem contra a morte. Ele integra esse movimento junto com a Canção Nova (emissora da Renovação Carismática Católica) e acredita que a vida vencerá a morte. Diz que a maioria do povo brasileiro é contra a legalização do aborto, $82 \%$ ou mais, citando a mesma pesquisa. Ele canta sua composição "O dom da vida":

O mais sublime dom

Que Deus pode nos dar

É a nossa própria vida,

Presente de quem sabe amar

A vida é o valor maior

Reflexo de Deus que é fecundidade

Fruto do mais perfeito amor

Eis, para nós, o verdadeiro milagre

A sua presença em nós nos une em aliança

Pois o Senhor nos traz a vida plena em abundância.

O deputado Givaldo Carimbão (PSB-AL) diz que veio defender a vida. Conta sobre sua família: tem uma irmã carmelita descalça e dois parentes padres. Ele se identifica como autor do projeto que transforma o aborto em crime hediondo. Reconhece a dificuldade de aprovação do projeto. Conclui: "Se Deus dá a vida, só Deus pode tirar a vida."

Padre Pedro afirma que os países que legalizaram o aborto agora legalizam a eutanásia: "Aborto é matar o filho e eutanásia é o filho que mata o pai."

Uma mulher testemunha ter gerado um filho com hidrocefalia. "Disseram que eu poderia tirar essa vida de dentro de mim." Ela, porém, não fez o aborto. Além do aspecto ritual, na vigília, vários elementos discursivos foram empregados para argumentar contra o aborto de anencéfalo. Foram acionados argumentos da esfera jurídica, como o país ser signatário de documentos

6 O deputado é cantor e pertence à Renovação Carismática Católica. 
internacionais que protegeriam a vida desde a concepção, além da previsão legal de direitos ainda na fase intrauterina com pensão de alimentos gravídicos. Constata-se uma conjunção do argumento legal sobre o feto anencefálico ter direito à vida e o valor judaico-cristão da vida como dom de Deus (Franklin, 1995), presente inclusive no cântico de autoria do deputado Eros Biondini, oriundo da Renovação Carismática Católica. Também se acionou o argumento político do direito da opinião da maioria prevalecer sobre o da minoria, mencionando pesquisas de opinião com rejeição do aborto por imensa maioria. Nesse repertório, cruzam-se argumentos ecológicos e bioéticos, como contrastar a proteção ao ovo de tartaruga por parte do Ibama e a proteção que seria devida ao feto humano anencefálico. Também se evoca o dilema psicológico: aborto como ação traumática que causaria arrependimento e a resistência de mulheres à indicação de abortar. Há o aspecto ritual: vigiar durante a noite, o uso de velas, cânticos e rezas, alguns deles específicos sobre o tema religioso do dom da vida, além dos testemunhos. Esses elementos conjugados produzem um efeito no grupo. Bourdieu (2011, p. 213) comenta sobre os efeitos de encenações religiosas, que, além de oferecer uma representação solene do grupo, teriam a "intenção mais obscura" de "ordenar os pensamentos e de sugerir os sentimentos mediante o ordenamento rigoroso das práticas, a disposição regulada dos corpos, e especialmente da expressão corporal da afeição".

A vigília estendeu-se pela noite e encerrou-se por um ato católico matutino às $7 h$.

Apesar de ser uma vigília ecumênica, até o momento de minha saída, não fora anunciada a presença de nenhum evangélico. Na manhã do dia 12 de abril, visitei a sede da Frente Parlamentar Evangélica (FPE), para inquirir e descobri que a terça-feira à noite era hora de reunião da frente. Além disso, havia sessão no Congresso Nacional. Três deputados evangélicos compareceram mais tarde após a votação no Congresso que terminou às 20h30: João Campos (PSDB-GO), presidente da FPE, Marcos Feliciano (PSC-SP) e Filipe Pinheiro (PSC-RJ). O deputado Marcos Feliciano escreveu uma carta convocando cristãos para essa vigília contra o aborto, e relatou a crítica de evangélicos por apoiar uma vigília promovida pela Igreja Católica na qual haveria um andor (Martins, 2012). Sobre a ausência de evangélicos, o funcionário da FPE alegou que evangélicos não teriam o hábito de se juntar com os católicos para atos religiosos. Pragmaticamente, afirmou que a vigília "não trazia votos". Eles se juntavam nas votações. 
Considerava correto os católicos fazerem uma vigília, afinal, todos os ministros eram católicos exceto um, Fux, de "cultura judaica". Na reunião da FPE, o casal apresentou a filha (Vitória de Cristo) sem cérebro e que sobreviveu, sinal do poder de Deus. "Só Deus tem o poder de dar e tirar a vida." Comenta ainda sobre o possível resultado do julgamento: "Lá eles ganham. Aqui não ganham, não. A diferença é que parlamentar é eleito pelo povo e os juízes, não." Esse comentário perspicaz mostra as dinâmicas da religião militante ocupando o espaço público: no Congresso Nacional, os evangélicos podem se aliar a católicos em função de causas conjuntas, como é a oposição ao aborto, por outro lado, se mantém a dinâmica de evitar a mistura e a contaminação no contexto ritual: evangélicos e católicos não celebram juntos. Essa contraposição do puro e do impuro (Durkheim, 1989) poderia ser desencadeada por uma celebração ecumênica onde estavam presentes católicos e espíritas. Não se repetem nos rituais, mesmo que em prol da mesma causa, as alianças observadas no Congresso Nacional referentes ao aborto e à proteção do chamado direito à vida de fetos e embriões (Luna, 2013), isso no parlamento que representaria o espaço público em sua dimensão estatal e o próprio Estado laico. Essa separação ilustra características dos pentecostais, a maioria dos evangélicos no país: uma forte identidade que demanda adesão exclusiva e uma noção de ética em que um código opõe a totalidade da vida em termos de julgamento do bem e mal (Sanchis, 1994). No espaço ritual público, tais evangélicos não admitem a mistura com os católicos.

\section{Cerimônia antes do julgamento}

De manhã se desenrola uma cerimônia litúrgica envolvendo menos de 40 pessoas vestidas com camisetas de pastorais da Igreja Católica, além de padres e freiras de hábito. Algumas camisetas estampam a frase "aborto não". Uma mulher traja uma camiseta de Santa Gianna abraçada com um bebê com os

7 Comentário semelhante contrastando a decisão no Judiciário com uma possível votação no parlamento ocorreu quando a Suprema Corte dos Estados Unidos julgou a ação Roe versus Wade, que legalizou o aborto no âmbito de todo aquele país (Dworkin, 2003). 
dizeres em italiano "prega por noi" (orai por nós). ${ }^{8}$ Um padre proclama uma fórmula de exorcismo. Uma imagem de Nossa Senhora de Fátima é carregada em andor por quatro homens. São repetidos orações e discursos contra o aborto. Um homem ligado à Renovação Carismática Católica em Goiânia entoa um cântico de sua autoria representando a perspectiva do feto abortado. Uma jornalista da Rede TV cobre o ritual.

Os pôsteres e faixas pendurados nas grades móveis que cercam o STF estão visíveis: fotos de fetos abortados em avançado estágio de desenvolvimento, de pedaços de fetos e de embriões sanguinolentos, e de métodos contraceptivos reputados de abortivos; outros justapõem essas fotos às do genocídio nazista e comparam o número de mortes. Expõem pronunciamentos favoráveis ao aborto provenientes de líderes acusados de genocidas, como Lênin. ${ }^{9}$ Alguns são explicitamente religiosos e pedem a intervenção do Sagrado Coração de Jesus ou avisam que Jesus, o Salvador, nasceu de uma gravidez que deu errado. Novamente confronta-se a proteção a fetos e a ovos de tartaruga. Casanova (2010) assinala a apropriação pela Igreja Católica do discurso dos direitos humanos e da defesa da dignidade da pessoa desde o papado de João XXIII como o meio de reconstruir o seu lugar no espaço público em termos globais e de assumir uma perspectiva universalizante. A vigília, o culto matinal e os cartazes antiaborto assumem essa retórica, associando elementos reconhecidos como religiosos: a santa no andor, a foto de Santa Gianna, a fórmula de exorcismo, cantos e orações. Nesse sentido, o ritual religioso vai mobilizar e criar um público consoante à reivindicação antiaborto ou em defesa da vida defendida pela Igreja Católica. Segundo Montero (2016, p. 144), “a própria atividade coletiva de colocar em cena certos confrontos constroem [sic] certos atores como 'religiosos' e a religião como 'pública', assim vigília e culto matutino são rituais que resultam "das dinâmicas de publicização colocadas em ação pelos atores na disputa pela atenção pública".

8 Santa Gianna Beretta teve diagnosticado um tumor em sua em sua quarta gestação e recusou-se a fazer aborto ou retirar o útero, submetendo-se a uma cirurgia que retirou o tumor, preservando a matriz. Ela morreu poucos instantes após o nascimento da criança saudável. Ela era médica, casada e mãe de três filhos. Cf. no portal da Canção Nova (Quem..., 2014). 


\section{O julgamento}

\section{A entrada}

Forma-se fila para entrar no STF. A seleção para a entrada é rigorosa: homens devem trajar blazer, gravata, calça social e sapato, e mulheres devem vestir blazer ou casaco. Algumas pessoas são advertidas na fila e se retiram para providenciar roupas adequadas. Entram religiosos de hábito e de batina e outros aparentando ser profissionais de direito trajados em estilo social. Quando entrei, liberaram o uso de xales, mas tive que manter os braços cobertos todo o tempo para evitar advertência pela segurança. Pessoas e bolsas passam por detectores separados. É proibido gravar o julgamento e apenas fotógrafos autorizados podem registrar a entrada dos ministros. Fotos do plenário são permitidas nos intervalos. O plenário não lota. Uma mulher fala ao celular: "Afirma que não existe como diferenciar na ultrassonografia anencefalia e acrania." Uma representante da Associação Médico-Espírita do Brasil é entrevistada, e mostra posição contrária ao pleito, justificando, quando indagada sobre o sofrimento da gestante, com pesquisas que associam opção por aborto à depressão.

Os ministros entram em fila e tomam seus lugares. Auxiliares levam peças do processo. O presidente Cezar Peluso abre os trabalhos.

Fala primeiro o relator Marco Aurélio Mello. Segundo a ADPF 54, com base no princípio da dignidade da pessoa e do direito à saúde, os artigos 124, 126 e 128 do Código Penal seriam inconstitucionais no caso da gestação de anencéfalo, quando se pleiteia a antecipação do parto. O ministro cita amici curiae (amigos da corte): CNBB, Conectas Direitos Humanos, Associação Pró-Vida e Pró-Família, Católicas pelo Direito de Decidir e Associação Médico-Espírita do Brasil. O relator descreve a audiência pública realizada em 2008. Do lado contrário à ADPF 54, alegou-se que a expectativa reduzida de vida não limita o direito do anencéfalo, afirmando o direito inviolável à vida do feto e a convenção de defesa dos direitos da pessoa com deficiência física. Alertou-se sobre a dúvida de obter um diagnóstico mostrando a letalidade total da anencefalia. Já os favoráveis à ação afirmaram que a manutenção da gravidez de anencéfalo contra a vontade da mulher equivaleria à tortura e feriria a dignidade humana. Afirmou-se que o SUS teria condições de oferecer os exames para o diagnóstico e que na época da formulação do Código Penal, 1940, não havia técnica para detectar anomalias. 
Dr. Luís Roberto Barroso, advogado da autora da ação ADPF 54, a Confederação Nacional de Trabalhadores da Saúde, afirma que é direito da mulher não ser um útero a serviço da sociedade, mas escolher. Alega ser a anencefalia incompatível com a vida extrauterina. A lei estabelece o aborto como crime quando há potencialidade de vida, mas não há vida (no anencéfalo), portanto, ele conclui não se tratar de aborto. Defende ainda que a criminalização da interrupção da gestação quando o feto não é viável fora do útero viola os direitos da mulher e que se trata de criminalização seletiva, afetando as mulheres pobres, enquanto a classe média tem acesso a aborto seguro. Ele sintetiza seus argumentos em quatro pontos: 1) (quanto à antecipação de parto de anencéfalo) não se trata de aborto; a totalidade dos representantes de associações científicas concordou que a letalidade é de 100\%; 2) incidiria nas exceções do Código Penal; 3) os artigos do Código Penal seriam paralisados pelo princípio da dignidade humana; 4) a criminalização viola os direitos da mulher e enfatiza a desigualdade.

O procurador-geral da República Roberto Gurgel fala que a vida está no centro de todos os debates. Ambas as visões se atêm à preocupação com a vida, embora com visões distintas: $65 \%$ dos anencéfalos morrem já no parto e os restantes vivem poucas horas. A continuidade da gravidez pode causar danos à saúde da mãe e risco à vida. Considera que estão implicados também o direito à liberdade e o direito à privacidade. $\mathrm{O}$ argumento da dignidade da pessoa humana autoriza o aborto (de anencéfalo). A Constituição proporciona proteção à vida intrauterina, porém de menor intensidade que a proteção à mulher. Com respeito à proteção à vida intrauterina: a tutela é mais exigente à medida que avança a gestação, o que não se aplicaria no diagnóstico de anencefalia. Ele rejeita a hipótese de ser aborto eugênico.

\section{Voto do relator Marco Aurélio Mello}

O ministro relata que, até 2005 , haviam ocorrido três mil autorizações judiciais para aborto em caso de diagnóstico incompatível com a vida, o que mostra a necessidade de o Supremo se manifestar. Busca interpretar os postulados da Constituição. Diferencia aborto e antecipação terapêutica de parto. Haveria um conflito "aparente" de direitos fundamentais. É necessário perguntar se a mulher deveria ser presa por um aborto nesse caso e se a lei impediria o procedimento. O Estado laico garante princípios: dignidade da pessoa humana, 
defesa da vida e autonomia. A Constituição da República admite a laicidade, assegura a liberdade de crença religiosa e garante o Estado laico. Exemplifica com a abordagem laica no julgamento da ADI 3510. A existência de liberdade religiosa e do Estado laico significa que a religião não guiará os princípios do Estado acerca da liberdade de reprodução, liberdade de orientação sexual, o princípio da dignidade da pessoa humana e da autonomia. O ministro define anencefalia. O diagnóstico corrente é de letalidade em 100\% dos casos, dado reconhecido por opositores à tese da ação na audiência pública. O relator afirma a tese: "Quem não tem cérebro não tem vida." Especialistas contestaram o diagnóstico de anencefalia de Marcela de Jesus, corrigido para meroaenencefalia ou merocrania, por estruturas do cérebro que lhe garantiram sobrevida. Ultrassonografistas experientes saberiam diferenciar o diagnóstico. A sugestão de levar a gestação do anencéfalo a termo para doar seus órgãos para transplante é considerada impossível por dois motivos: 1) não se obriga a nenhuma doação, o que seria tratar a mulher como um instrumento; 2) os órgãos do anencéfalo não são passíveis de doação, porque portam alterações que contraindicam o transplante. Quando a gravidez se apresenta como processo mórbido, se não há como salvar a vida do feto, interromper não constitui crime de aborto.

O relator considera que falta provisão expressa no Código Penal de 1940. $\mathrm{O}$ aborto de anencéfalo estaria implícito no risco de vida para a mãe.

Menciona o julgamento da ADI 3510. A cláusula pétrea da Constituição no tocante ao direito à vida fala do indivíduo-pessoa. Mello afirma que no caso do anencéfalo não existe justificativa para tutela jurídico-penal, ainda mais quando obsta direitos da mulher. Declara o caráter não absoluto do direito à vida. No aborto humanitário (quando a gravidez é decorrente de estupro), o feto é viável, mas não se garante esse direito. Questiona: se o direito de fetos viáveis pode ser ponderado em relação aos direitos da mulher, quanto mais no caso de inviáveis? Ele reconhece existir divergência se a gestação de anencéfalo implicaria mais riscos para a saúde da mulher e cita os riscos alegados. Relata uma pesquisa da USP entre gestantes de fetos sofrendo anomalias incompatíveis com a vida, que demonstrou o alívio de mulheres em interromper a gravidez e $o$ sofrimento das não autorizadas. O ministro obsta que a mulher deveria decidir a partir de seus próprios valores. Ele rechaça o argumento de que "todos nascemos para morrer" e dirige-se ao presidente do STF Cezar Peluso como autor da afirmativa. Peluso contesta: ele disse que "todos nascemos para viver". O relator 
considera violência a mulher não poder decidir em um casos desses, o que vai contra sua autonomia. O relator julga procedente a ação. Diz que foi triste o dia em que se suspendeu a liminar, o que deixou as mulheres brasileiras a seguir sua via crucis.

\section{Intervalo}

A sessão é interrompida para almoço. Uma jornalista indaga ao geneticista Thomas Gollop (um especialista expositor na audiência pública) se há diagnóstico para diferenciar o caso de Marcela de Jesus de anencefalia e se isso seria contemplado pela decisão do STF. Ela se refere à menina Vitória de Cristo, portadora de acrania e anencefalia que, levada pelos pais, circulou no julgamento, onde foi apresentada aos ministros do STF, e também no Congresso Nacional, inclusive na reunião da FPE. O bebê não tinha cérebro, mas tinha couro cabeludo protegendo o encéfalo sem os ossos da parte superior do crânio. ${ }^{10}$ Gollop responde que não há diferença porque são casos de morte cerebral, nuances de anomalias de formação do sistema nervoso implicando graus diferentes de sobrevida. A jornalista insiste em saber se é variação de anencefalia para ver se a interpretação do STF se aplicaria. Ele confirma. Eu pergunto sobre a frequência da anencefalia. Gollop responde que um a cada mil nascimentos. Havia apenas dez registros de meroanencefalia, caso de Marcela de Jesus, e acrania era um tipo próximo. O geneticista foi taxativo na declaração: não é vida humana. Não há vida sem coração, sem rins e sem cérebro. Exemplifica que se fosse atropelado e entrasse em morte cerebral, ele também não seria mais vida humana, seus órgãos poderiam ser doados.

Saindo, vejo Vitória de Cristo, carregada pelos pais, uma bebê com olhos enormes, e couro cabeludo cobrindo um crânio que acabava na altura das sobrancelhas, sem volume nem ossos na parte superior. Uma mulher fala com o casal: "É tudo mentira, claro que é vida..."

Na retomada da sessão, os ministros falam em sequência a partir do empossado mais recente ao mais antigo, e por último, o presidente do STF.

10 Ela viveu por "dois anos e meio fora do útero" e "nove meses de gestação", conforme consta no blog criado por seus pais "Nossa amada Vitória de Cristo" - http://amadavitoriadecristo.blogspot.com.br/ (acesso em 15/12/2013). 


\section{Rosa Weber}

Ficou sensibilizada com a visita dos pais da menina Vitória. Quanto à sobrevida prolongada de casos de anencefalia como os de Vitória e de Marcela, ela se pergunta se seriam erros de diagnóstico.

A ministra volta-se para o debate no direito sobre a regulação da vida. Ela identifica variação da reprovabilidade dos crimes contra a vida nos artigos do Código Penal. Em gravidez decorrente de estupro, não haveria interesse de defender o direito do feto contra o direito da mulher. Cita o jurista Nelson Hungria: no caso de aborto, o crime lesa a vida do feto. $O$ feto é protegido pelo direito, mas a personalidade jurídica se dá no nascimento com vida, aí se concretiza o exercício dos direitos. A lei de transplante de órgãos define como morte a cessação da atividade cerebral. Entre os critérios para o diagnóstico está a incapacidade de interação. A vontade do legislador (de 1940) não pode contrariar a Constituição. Rosa Weber adota o procedimento de ponderação de valores: há dúvida sobre os direitos do feto, enquanto não há dúvida sobre o direito da gestante, podendo se prever a opção em manter a gravidez. A posição contrária implica obrigar a mulher a continuar a gravidez e fere sua autonomia. Acatando a proporcionalidade e o princípio da dignidade da pessoa humana, a decisão é pela autonomia da gestante em escolher.

\section{Joaquim Barbosa}

O ministro quebra a sequência. Repete o voto do processo do habeas corpus que foi publicado e pede a juntada do voto no processo. Trata-se do caso Gabriela, um pedido de habeas corpus solicitando autorização para aborto de feto acometido de anencefalia, o primeiro que chegou ao Supremo.

\section{Luiz Fux}

O ministro inicia dizendo ter agradecido a Deus pela oportunidade de votar e contribuir para diminuir o sofrimento das pessoas, e pedido para equilibrar razão e emoção. Ele lê uma carta de uma mulher a quem foi negada a autorização para o aborto em gestação de anencéfalo, esperando 9 meses para ver a missa de sétimo dia de seu filho. Ele destaca a frequência no Brasil com 10 casos 
a cada 10 mil nascimentos. Viu, em programa de televisão, uma mulher declarando equivocadamente que o Supremo iria impedir a mãe de esperar e abraçar seu filho. A dignidade da pessoa humana desafia a bioética. Admite o encurtamento da vida para garantir a dignidade. Ele afirma três pontos: a vida efêmera do anencéfalo; razoável certeza do diagnóstico; inexistência de recurso terapêutico para o feto. Segundo pesquisa com mulheres que anteciparam o parto de anencéfalo, elas declaram reduzido o sofrimento, e pretendem retomar a vida reprodutiva. Para Fux, obrigar a prosseguir a gestação produz chagas que não cicatrizam. Menciona riscos. Considera que o bem jurídico é a saúde da mulher. Alerta que os hodiernos métodos de diagnóstico inexistiam na formulação do Código Penal. Cita o Código Penal que admite o aborto em caso de estupro quando o feto é sadio. A criminalização do aborto de feto anencefálico agrava os custos do Estado, sendo proibição ineficaz. Comenta que o aborto clandestino no Brasil acontece em todas as classes sociais.

Ministro Marco Aurélio faz um aparte: "As ricas em boas condições e as pobres com açougueiros."

Fux concorda e afirma ser o aborto um problema de saúde pública e não do direito penal. No caso da anencefalia, seria punir pelo punir. O Supremo respeita as mulheres que pensam diferente, mas aquela que opta pelo aborto de anencéfalo segue a lei.

\section{Cármen Lúcia}

Declara que de todos os lados há preocupação com a vida e o direito à vida. Segundo a ministra, o útero é o primeiro berço, e compara no tocante à anencefalia: "O berço se torna um esquife." Ela fala da dignidade da mãe. Pondera que a decisão pela interrupção no caso da anencefalia também é uma decisão trágica. Considera o direito das mulheres, e o significado para as famílias envolvidas, pai e irmãos. Há medo e vergonha no caso da mulher que opta pela interrupção.

\section{Ricardo Lewandowski}

O ministro adianta que seu voto será contrário ao dos demais colegas - as mulheres do Movimento Brasil sem Aborto sorriem, após desânimo com 
votos anteriores. Ele nega a ação ser contemplada pela lei. Considera que o Congresso Nacional, o legítimo legislador, poderia ter mudado a lei para contemplar anencefalia, mas não o fez. Afirma: "Quando a lei é clara, não há espaço para interpretação." Ao STF só cabe o papel de legislador negativo, isto é, retirar da lei as normas que contrariam o texto magno. Conforme a divisão de poderes, não caberia ao Judiciário agir como legislador. Lewandowski adverte que a anencefalia é uma doença congênita letal, mas há outras como agenesia de rins e osteogênese imperfeita letal. Pergunta: "Por que se escolheu a anencefalia para isentar de punição o aborto?" A aprovação no caso de anencefalia acarretaria incluir as que implicam pouca expectativa de vida. Comenta a existência de dois projetos de lei em tramitação no Congresso Nacional.

\section{Cezar Peluso}

O presidente do STF marca a próxima sessão para o dia seguinte às $14 \mathrm{~h}$.

\section{Plenário e saguão}

Há burburinho após o encerramento. Alguns lamentam não poder voltar para ver o resultado. O pleito ficou a um voto da maioria absoluta a favor da ADPF 54 . Uma liderança do Movimento Brasil sem Aborto telefona após o último voto e elogia Lewandowski. Outras mulheres desse movimento sorriem aliviadas.

Converso com uma advogada feminista, coordenadora de ONG. Eu comento sobre o agradecimento a Deus pelo ministro Fux. Ela responde que ele não é cristão, é judeu, por isso podia dizer graças a Deus no início de sua fala.

Pessoas cercam Severina e o marido. ${ }^{11}$ Eles são assediados. Vários querem falar com eles, inclusive o relator, Ministro Marco Aurélio Mello, a quem Severina é apresentada.

11 O documentário de Debora Diniz retrata a história de Severina: ela está internada para interromper a gestação de anencéfalo, quando é cassada a liminar do STF. Mostra o relato do casal para obter a autorização judicial, a ida de Severina para uma maternidade fazer a indução do parto, o nascimento do filho morto e o enterro (Luna, 2014). 
Uma advogada critica o argumento formal de Lewandowski, de que o Supremo não poderia legislar, pois no início, o plenário julgou a ação admissível.

Um advogado envolvido na ação comenta que se avançou muito no debate não restrito à anencefalia, mas do aborto em geral. Os ministros falaram de autonomia reprodutiva da mulher e de risco para a saúde. Ele avaliou: ainda não dá para aprovar o aborto no Supremo hoje.

O clima era festivo entre os favoráveis à ação.

\section{Dia 12 de abril de 2004}

No dia seguinte, o plenário não estava cheio. Um professor de direito levou uma turma para assistir. As lideranças do Movimento Brasil sem Aborto faltaram. Não há religiosos vestindo hábito.

O presidente abre a sessão.

\section{Carlos Ayres Britto}

Declara que o dispositivo do Código Penal está manifestamente contrário ao entendimento da Constituição. Não deveria haver impedimento de interromper uma gestação quando esta constitui uma "fraude" (sic). Não existiria crime contra a vida. $\mathrm{O}$ ministro cita dados sobre a letalidade.

O ministro entende aborto como expulsão do feto. A Constituição não define o início da vida. Rejeitou-se na Constituinte a definição do início da vida na concepção. Nega existir o crime de aborto quando o feto é um natimorto cerebral. Trata-se de um ser a meio caminho do humano. A criminalização do aborto se dá como proteção de uma vida humana em potencial.

O ministro considera o abalo psíquico e a dor da gestante como bens jurídicos a tutelar. Já o anencéfalo não tem capacidade de vida extrauterina. Essa gestação pode trazer outras consequências para a mulher. Compara com a exclusão de punibilidade do aborto na gravidez decorrente de estupro. Afirma que o grau de civilização de uma sociedade se mede pelo grau de liberdade da mulher. Fala no direito de optar da gestante. A mulher não deseja ver o produto da concepção involucrado em mortalha. Ele concorda com a tese que impor esse martírio é uma situação de tortura. 


\section{Gilmar Mendes}

O ministro discordou da negação do pedido de amicus curiae para a CNBB, e ironiza se essa atitude de "faniquitos anticlericais" se estenderia à exclusão de elementos culturais oriundos da história cristã, como o calendário gregoriano e a celebração do Natal.

O ministro Fux, discordando de Mendes, ressalta que os encaminhamentos da véspera foram do pluralismo e não da intolerância.

O ministro Gilmar Mendes passa para o direito comparado. Afirma que a relação entre mãe e filho é uma relação de dualidade. Há vários temas ligados à doutrina da personalidade. Considera o caso diferente da morte encefálica. Lista riscos da gestação de anencéfalo. Comenta o sofrimento psíquico da mulher. Na gestação de anencéfalo não há vida humana viável em formação. Comenta as duas hipóteses em que o aborto é permissível. Afirma que a legislação ainda não regulou o aborto do anencéfalo, embora sua justificativa seja a mesma: o sofrimento psíquico da mãe. Considera premente a necessidade de atualização do Código Penal. Ressalva que a decisão manipulativa de conteúdo aditivo (aquela que acrescenta uma interpretação à lei) deverá servir de estímulo ao legislador e não impedirá que tome as deliberações. Sugeriu diferentes médicos para emitir o laudo e realizar a cirurgia.

\section{Intervalo}

No intervalo, vários jornalistas se aglomeram para fazer perguntas aos ministros Britto e Lewandowski, que se colocam atrás da corda que separa o lugar dos ministros e o lugar do público. Um deles pergunta se os adendos propostos por Gilmar Mendes vão fazer parte da decisão. Britto diz que o relator tem que concordar. Indagado, ele ressalta a diferença entre o procedimento médico do aborto e o crime de aborto. Um dos jornalistas pergunta sobre o questionamento formal feito por Lewandowski, e Britto responde ser uma preocupação legítima. Jornalistas cercam o advogado Luís Roberto Barroso.

\section{Celso de Mello}

O ministro declara que assim como no julgamento da ADI 3510, nunca participou de um processo de tal monta quando se discute o alcance da vida e 
os mistérios da morte. Há dilemas éticos e jurídicos resultantes do litígio em debate. Concorda com a vinda dos amici curiae para o julgamento.

\section{Marco Aurélio Mello}

O relator objeta que eles estiveram presentes na audiência pública.

\section{Celso de Mello}

O ministro insiste na sugestão que os amici curiae participem mais efetivamente do processo para não se criar um déficit de constitucionalidade. O julgamento não pode ser visto como disputa entre o Estado e a Igreja. Relembra a separação entre Estado e Igreja desde a Constituição da República datada de 1890. A laicidade do Estado como princípio fundamental na Constituição brasileira reconhece a liberdade de religião, de crença, de consciência e de culto. Preserva-se a separação entre Estado e Igreja. A escolha de fé religiosa revela-se questão privada. Segundo o ministro, o STF reconhece que, nos casos comprovados de anencefalia, a mulher apoiada em seus direitos reprodutivos, baseada no princípio da dignidade humana, pode decidir interromper a gravidez ou continuar. Ele diferencia a antecipação terapêutica de parto dos casos de aborto. Afirma que a Constituição e o Código Penal não estabelecem o início da vida. O ministro define os direitos fundamentais da mulher como relacionados ao exercício da sexualidade e da procriação.

Celso de Mello não questiona a sacralidade e inviolabilidade do direito à vida, independentemente de confissão religiosa. Ressalta o postulado de dignidade da pessoa humana enquanto princípio interpretativo do direito constitucional, bem como o princípio de liberdade e de autodeterminação pessoal. Segundo Mello, o julgamento propõe refletir sobre o início da vida, sobre o momento em que o ser humano se regula como ente.

\section{Carlos Ayres Britto}

O ministro faz um aparte, citando Debora Diniz: "O início da vida é um regressar infinito, porque as células são vivas." 


\section{Ricardo Lewandowski}

Afirma ser o feto anencefálico uma verdade insofismável e única. Argumenta que existem graus de anencefalia que permitem certo tempo de vida, inclusive de vida de relação. Julga necessário regulamentar isso.

\section{Celso de Mello}

Segundo o ministro, há vários inícios da vida. Segundo o ordenamento jurídico brasileiro, sabe-se o conceito de vida a partir da definição da morte. O conceito de vida baseado na presença de batimentos cardíacos foi substituído pelo conceito de morte encefálica. O ministro trabalha com o princípio da proporcionalidade e a técnica de ponderação de direitos. Cita documentos internacionais que falam da inviolabilidade do direito à vida, discordando do início do direito desde a fecundação. O ministro comenta a judicialização da medicina. Ocorre demora em conceder a autorização a ponto de a criança nascer. Falta respeito à decisão dos pais. Avalia que médicos se recusam a fazer o aborto, sem discordar do procedimento, por receio da lei. Mello menciona os riscos dessa gravidez para a gestante e a impossibilidade de anencéfalo doar órgãos. Segundo Mello, inexiste motivo racional a levar a mulher a prolongar a gravidez, o que pode implicar risco de morte.

O ministro Celso de Mello pede que se acolha a sugestão do ministro Gilmar Mendes no sentido de garantir que médicos diferentes façam o diagnóstico e a cirurgia, e de pedir a normatização pelo Ministério da Saúde, acrescentando o pedido ao Conselho Federal de Medicina.

\section{Marco Aurélio Mello}

O relator diz que seu voto pede a comprovação. Referindo-se a essas últimas especificações, o ministro diz não querer tomar o lugar dos médicos.

Os ministros Mendes e Celso de Mello insistem na necessidade de regulamentar esses aspectos, discutindo esse tópico específico, como se o julgamento já houvesse terminado. A maioria de seis dos dez votos favorável à tese da ADPF 54 foi obtida no pronunciamento de Carlos Ayres Britto. Faltava o voto final do presidente do Supremo Tribunal Federal, ministro Cezar Peluso. Este pede para ser retomada a votação e lê seu voto integralmente. 


\section{Cezar Peluso}

O presidente também considera que esse é um julgamento importante, porque trata do valor da vida. Declara: "Tenho que ser fiel às mais profundas convicções jurídicas." Seu voto dista da decisão sobre células-tronco (ADI 3510), por conta dos embriões que permaneciam congelados. Defende a noção de vida como processo em que o princípio causal está no próprio movente, ausente nos embriões congelados. Afirma: "Vida não é um conceito operacional criado pela ciência jurídica." Vida e morte são fenômenos pré-jurídicos. Assegura que a definição legal de morte encefálica tem caráter operacional para obter órgãos para transplante, por isso não está infensa a questionamento jurídico ou científico. O ministro avalia que a audiência teve resultados controversos de especialistas quanto à atividade cerebral no anencéfalo.

O ministro questiona os princípios de liberdade, autonomia, legitimidade e vontade. Essa conduta (do aborto) é banida pelo direito penal. Basta a eliminação da vida intrauterina ou extrauterina. Assevera ser "indisfarçado cometimento de um crime. Pena capital para o feto anencefálico", reduzindo o feto à condição de lixo: "É forma de discriminação que não difere do racismo, sexismo e especismo." Considera-o incapaz de se defender: "Vestes de monstruosidade são atribuídas ao anencéfalo."

Segundo Peluso, com a proposta da ADPF valeria eliminar o anencéfalo nascido vivo em nome da vida e da saúde psíquica da mãe. Pergunta como admitir isso, pois considera que a vida intrauterina e extrauterina têm o mesmo valor. Defende a preservação da vida intrauterina mesmo com deformidade, caso contrário o feto não seria sujeito, mas objeto.

Afirma ser a vida um fato aferível e irredutível por critério de prognóstico. Prossegue dizendo que doenças incuráveis não autorizam a antecipação da morte, no confronto do aborto de anencéfalo e da eutanásia: ambos se aproximam em nome da autonomia e da dignidade. Associa o aborto de anencéfalo à ameaça eugênica. Assevera a mulher não ter direito sobre o feto. Contrasta com a ADI 3510 que abordava vida congelada. $O$ estado atual da ciência médica não teria como distinguir as formas de anencefalia e de meroanencefalia.

O ministro contesta a comparação do padecimento materno à tortura. Tortura designa sofrimento injusto e intencional. Reitera o direito à vida e à dignidade do feto. Pergunta ironicamente quem torturaria a mulher: o feto 
anencefálico, o Executivo, o legislador ao não fazer a lei, ou o Judiciário ao não criar a impunibilidade. Afirma ser o sofrimento inerente à vida humana. O sofrimento resulta de pessoas livres que engravidaram, o que não é produto de força humana exógena. A causa real da pretensa tortura é uma falha biológica na constituição do feto sem intencionalidade. Argumenta que o direito à liberdade é inexistente quando há crime. Qualifica esse argumento de "comodidade da gestante para evitar o sofrimento", o que impede o exercício das virtudes de compreensão e misericórdia. O presidente do STF contrasta dois valores de peso axiológico distintos: o sentimento transitório da dor e a vida do anencéfalo, bens jurídicos desproporcionais. Distingue do caso de aborto resultante de estupro em que há a violência do forçado intercurso sexual. Alega que se há injustiça, só no plano místico, mas não no plano do direito. Rejeita o argumento de a gestação de anencéfalo constituir risco de vida para a mãe, o que já está previsto. Refuta a invocação do direito à saúde, sendo mais seguro proibir a gravidez, pois toda gravidez implica risco. Conclui seu voto afirmando que cabe ao legislador fazer a lei. A ação quer contornar a má vontade do Congresso Nacional de fazer a lei. A ADPF 54 transpõe aos ombros dessa corte essa responsabilidade. $\mathrm{O}$ ministro considera-se solidário com o sofrimento da mãe.

Durante o voto de Peluso, uma católica ligou para uma liderança do Movimento Brasil sem Aborto para dizer que ele havia citado a exposição dela. Ela permaneceu durante a leitura desse voto com a mão erguida e mexendo os lábios em postura de oração.

\section{Cena final}

Encerrada a leitura do voto de Peluso, o ministro Carlos Ayres Britto comenta que esse voto foi coerente com quem acredita que as pessoas nasçam para morrer, enquanto Britto mantém que acredita que as pessoas nasçam para o espetáculo da vida.

Os ministros discutem o adendo de Gilmar Mendes que exige médicos diferentes para o laudo e para o procedimento do parto. Fux pede que o voto se mantenha como está para evitar complicações e se diz sem capacidade técnica de avaliar as condições propostas. Celso de Mello e Gilmar Mendes insistem nas condições. Fux diz que o Supremo deve ser minimalista. Rosa Weber 
se preocupa que, em um Brasil continental, a condição não obtenha o efeito pretendido. Cármen Lúcia mantém seu voto com as mesmas preocupações de Rosa Weber. O presidente Cezar Peluso ressalva que ele e Lewandowski não votam sobre aquele ponto (eles não podem discutir as condições, pois foram contra a tese da ADPF). O relator Marco Aurélio diz que o problema no Brasil é que se considera todo mundo salafrário. Um ministro observa que o problema não seria por conta da fraude, mas por erro médico. Lewandowski reconhece ter sido vencido, mas queria garantir o mal menor; que houvesse o segundo exame para segurança da gestante e do feto, inclusive com consentimento informado. Diante da dúvida da maioria, Marco Aurélio mantém o voto sem a sugestão.

Quando o presidente do STF, Cezar Peluso, declara o resultado do julgamento favorável à ADPF 54, no plenário esvaziado, uma mulher grita:

Parabéns, presidente. Parabéns, senhores ministros. Eu sou mulher, advogada e represento $80 \%$ da sociedade brasileira. Vocês fizeram história como Hitler fez história. Os legisladores são capazes de distorcer os conceitos para aprovar o que querem. Podem me chamar de louca, mas eu estou em uma sociedade democrática.

Ela se volta para outro alvo: "Parabéns, Dra. Debora Diniz. Parabéns, Dr. Luís Roberto 'Qualquer Coisa'. Eu me reverencio a vocês." Ela se curva e faz duas vezes um gesto de reverência com um dos braços varrendo o chão.

Dra. Debora Diniz, vai chegar a CPI do aborto e vocês vão perder o financiamento da Fundação MacArthur que vocês recebem. Anencéfalos são esses doutores e juízes que criam regras para matar inocentes. Não quero saber se tem mestrado ou doutorado. Vou para casa, amamentar meu filho que não é uma pessoa.

Uma católica acode a mulher que gritou e segura sua mão. Seguranças tentam acalmá-la e retirá-la. Eu me surpreendo com a flexibilidade da segurança diante daquela atitude, quando vigiaram o tempo todo se os xales descobriam os braços ou para onde se voltavam as câmeras. Alguns elogiam a reação dessa mulher. As jornalistas correram atrás para obter seu nome e identificação. Ela trabalha em um centro espírita de apoio a mulheres. Perguntam se o filho dela é anencéfalo e ela nega. Uma jornalista a chama para gravar entrevista. 
No táxi de volta, o motorista pergunta o resultado do julgamento. Ele diz que "os juízes do Supremo parecem não acreditar em Deus. Como podem decidir terminar a vida de alguém?". Ele repete a opinião que ouviu de uma juíza do STJ afirmando que iam fazer laudos falsos para fazer aborto. Eu pergunto a sua religião, e ele é evangélico.

\section{Considerações finais}

Etnografias de eventos públicos sobre o aborto mostram a polaridade dos segmentos antiaborto, autodesignados de pró-vida, e os de posição pró-escolha. Em instâncias públicas de caráter marcadamente político como o Congresso Nacional (Cunha, 2007) ou o Supremo Tribunal Federal, os grupos defendem suas posições como inconciliáveis. Ao contrário das sessões da audiência pública da ADPF 54, quando houve manifestações de representantes religiosos favoráveis ao direito de escolha (Luna, 2015), não foi possível observá-los na etnografia, o que pode ser uma limitação do método.

O julgamento da ADPF 54 no Supremo Tribunal Federal foi fator de mobilização de diversos segmentos da sociedade. Resistindo ao julgamento e seus resultados prováveis estavam religiosos de orientação pró-vida. Embora o Movimento Brasil sem Aborto se afirme laico, observou-se a presença de lideranças mais engajadas e combativas entre católicos e, em número menor, de espíritas, bem representados na vigília por associações espíritas de médicos e juristas. Constatou-se ali uma conjunção do argumento legal sobre o feto anencefálico ter direito à vida e o valor judaico-cristão da vida como dom de Deus. A ausência de evangélicos foi notável na vigília, mas eles estavam atentos ao julgamento como atesta a visita dos pais da menina Vitória de Cristo na reunião da Frente Parlamentar Evangélica, e o comparecimento tardio de três deputados evangélicos à vigília. Do lado dos contrários à ação, era forte o apelo visual com imagens de embriões destroçados ou fetos em avançado estágio da gestação. As comparações com o Holocausto eram recorrentes. A organização da vigília e do culto matutino pela Igreja Católica, bem como a presença significativa de religiosos e militantes assistindo ao julgamento sinalizam o ativismo conservador de católicos em reação às demandas e conquistas de direitos sexuais e reprodutivos, conforme identificado por Vaggione (2012). 
O prédio do Supremo é um espaço sagrado atualmente ritualizado, repleto de interdições que vão desde a roupa adequada à proibição do registro sonoro e de imagens. Coisas sagradas, segundo Durkheim (1989), são consideradas como superiores em dignidade e em poder com relação às coisas profanas. Nos intervalos, suspendiam-se temporariamente algumas interdições. Nos intervalos e após o encerramento, ocorria o momento communitas de encontro e congraçamento (Turner, 2003), alternado na maior parte do tempo com o momento estrutura de um ritual altamente formalizado. As celebridades do debate circulavam, figuras icônicas como Severina, Vitória de Cristo e a recordação indelével de Marcela de Jesus. Tais figuras constituíam símbolos, um referente que apontava para muito além da figura em si, englobando diversos significados (Turner, 2003).

No tocante à argumentação, destaco brevemente alguns pontos. Primeiramente o esforço retórico de renomear o procedimento para "antecipação de parto" em lugar de "aborto". A palavra "aborto", além do enquadramento jurídico, porta estigma, por isso a designação eufemística. Reporto-me a esse respeito a Fonseca e Cardarello (1999, p. 88) acerca do "poder instituinte das palavras, isto é, a construção social de certas categorias [...] enquanto mais ou menos merecedoras de direitos específicos". Tal é o anencéfalo, portador dos direitos de um ser humano pleno segundo a concepção dos ministros Peluso e Lewandowski, bem como dos ativistas antiaborto; por outro lado, não considerado um detentor de direitos em função da letalidade total da anomalia, de modo que os outros oito ministros priorizaram o direito específico da mulher. Em continuidade com o aspecto do "poder instituinte das palavras", o segundo ponto foi uma grande adesão à tese de que o anencéfalo constituía um natimorto cerebral, presente na resolução do CFM e nas falas da maior parte dos representantes científicos durante a audiência pública (Luna, 2013, 2015). Por outro lado, não se encontraram posições como a do médico geneticista Thomaz Gollop, que afirmou que anencefalia e variações não constituíam vida humana. Pelo contrário, ainda que na maioria acatassem a tese da equivalência com a morte cerebral, os ministros do Supremo argumentaram em cima das leis, buscando comparações que reiteravam que a defesa da vida não se encontrava referendada de modo absoluto, além de ilustrarem os diversos graus de reconhecimento da pessoa humana pelo direito. Muito importante foi o fato de a interpretação da maioria dos ministros considerar o risco para 
a saúde materna, em vez de se ater à letra da lei em que consta "se não houver outro meio de salvar a vida da mãe". Nesse sentido e na afirmação da autonomia reprodutiva das mulheres, o julgamento se aproximou das teses liberais do movimento pró-escolha.

Em ambos os lados, identificou-se o englobamento hierárquico no sentido de Dumont (1997). Para os favoráveis à ADPF 54, o princípio da ponderação garantia que o interesse da mulher deveria preceder o do feto inviável. $\mathrm{Na}$ perspectiva dos dois ministros que votaram contra, a vida do anencéfalo teria precedência. O ministro Peluso, em sua defesa do valor da vida intrauterina afirma a diferença de peso do sofrimento materno transitório e da vida do feto, mesmo deformado, que deveria ser respeitada. Nesse sentido, ele descarta todos os argumentos referentes à autonomia da mulher, exceto no caso de estupro, quando a mulher não tem autonomia nenhuma. O ministro Lewandowski faz uma pergunta crucial: diante de outras anomalias fetais incompatíveis com a vida, por que autorizar apenas o aborto no caso de anencefalia? Mais do que o risco de abrir a porteira para o aborto eugênico, o ministro toca em um ponto fundamental: não é apenas a viabilidade do fato, mas a representação de pessoa que está aí afetada. Sem racionalidade e vida de relação não há ser humano (cf. Luna, 2009). Nesse sentido, ambos os lados da disputa sacralizam o indivíduo. Em um lado a mulher é meio de desenvolvimento do feto e não é sujeito, mas o feto é. No outro, a autonomia feminina é preservada. Em comum nas duas posições está o culto ao ser humano como indivíduo (Durkheim, 1970), elemento característico das sociedades ocidentais modernas. Apenas Peluso defendeu a tese do dolorismo cristão, pela qual o sofrimento ensina qualidades de compaixão e misericórdia. Além do valor sagrado da vida intrauterina, foi esse o traço marcadamente holista do debate.

Chama atenção, em um debate tão acusado de ter viés religioso, que um ministro, no julgamento, explicite ter agradecido a Deus por poder participar da decisão e reduzir o sofrimento das pessoas. Como seu voto foi pró-escolha, não houve críticas quanto à infração contra o Estado laico.

É possível comparar a análise dos rituais de vigília e culto matutino que cercaram o julgamento da ADPF 54 no Supremo na tentativa de influir nos votos dos juízes e da opinião pública, com a análise feita por Montero, Brum e Quintanilha (2016, p. 726-727) do culto ecumênico pela morte de Herzog em 1975 e sua reedição em 2015: 
Foi possível localizar um campo categorial e normativo comum na elaboração da fala pública da Igreja Católica e daqueles que com ela se reuniram. Esse campo pode ser caracterizado a partir de pelo menos três propriedades principais. Em primeiro lugar, evidentemente, a ideia ordenadora e persistente dos Direitos Humanos que formula um espectro bastante amplo de experiências coletivas na linguagem cívica dos direitos. Em segundo lugar, a permanência de uma percepção do Estado como um inimigo a combater, o que faz da cidadania o exercício da resistência e da política um campo de luta e violência mais do que de argumentação e convencimento. [...] Finalmente, a descrição dos eventos tornou visível uma ideia de sociedade civil constituída fundamentalmente pelo arranjo da variedade religiosa.

Nos rituais e manifestações que cercaram o julgamento, estavam caracterizados discursos pró-direitos humanos, centrados no personagem do feto anencefálico por parte dos religiosos antiaborto, e centrado na mulher, pelos favoráveis ao direito de escolha. Em várias manifestações de religiosos na vigília, na cerimônia matinal antes do julgamento e no rompante de protesto final, os ministros do Supremo, representantes do Estado, eram o inimigo a combater, no sentido de não respeitarem a vida humana do anencéfalo. A variedade religiosa também esteve visível na presença de católicos, espíritas e evangélicos.

Quem são os sujeitos da fala autorizada nesse conjunto de rituais? No Supremo, os juízes, na vigília, os ativistas que tiveram acesso ao microfone, na maioria católicos, mas também espíritas, religiosos em hierarquia (bispos e padre falaram, depois os leigos falaram) representantes de associações médicas e de juristas que eram religiosas. Os atores religiosos colocam suas reivindicações publicamente nos atos abertos e nos rituais que acabam por se constituir como religiosos. Restaram os protestos desautorizados dos que resistiram à decisão do Estado.

Com respeito aos desdobramentos desse julgamento do Supremo, é possível apontar um recrudescimento conservador reativo verificado em outras decisões, como o julgamento da ADI 3510 (Luna, 2013). Antes a maior parte das manifestações na Câmara dos Deputados acerca da anencefalia em proposições legislativas era para sua prevenção mediante complemento alimentar, ou para a legalização do aborto de anencéfalo, exceto um projeto de lei contrário (PL 5166/2005). Com a decisão favorável a autorizar a antecipação de parto 
de anencéfalo, cessaram projetos pedindo a legalização desse tipo de aborto, mas surgiram projetos para sustar a decisão, ou incluiu-se anencefalia em projetos antiaborto. ${ }^{12} \mathrm{~A}$ portaria do Ministério da Saúde que visava incluir os procedimentos legais de interrupção da gestação na tabela do SUS em 2014 (Brasil, 2014) foi revogada depois de forte oposição de parlamentares religiosos, embora o ministério alegasse razões técnicas. ${ }^{13}$ Assim, é possível inferir como desdobramento que o julgamento acirrou o ativismo religioso conservador. Essas iniciativas em grupo ou manifestações individuais de protesto por parte dos religiosos referendam as teses de Casanova $(1994,2010)$ sobre a desprivatização da religião e sua entrada na esfera pública na modernidade, questionando os limites entre esferas pública e privada e participando das lutas para definir legalidade e moralidade. A observação etnográfica comprova a teoria da desprivatização no sentido de que ali se dispuseram agentes religiosos para defender o tradicional mundo da vida das investidas jurídicas do Estado, assumindo ainda o discurso dos direitos humanos. Essa posição de defender a tradição não se restringiu aos agentes assumidamente religiosos, mas estava presente nos votos dos ministros Lewandowski e Peluso contrários às liberdades individuais das mulheres e pró-vida fetal.

\section{Referências}

BERGER, P. L. O dossel sagrado: elementos para uma teoria sociológica da religião. São Paulo: Paulus, 1985.

BERGER, P. L. A dessecularização do mundo: uma visão global. Religião e Sociedade, Rio de Janeiro, v. 21, n. 1, p. 9-23, 2001.

12 Todos os itens foram localizados mediante a palavra-chave "anencefalia". Proposições antiaborto anteriores ao julgamento: PL 5166/2005, REQ 109/2009 CLP. Solicitam alteração na lei de transplantes para incluir anencéfalo como doador: PL 6599/2006, PL 1195/2007. Proposições antiaborto posteriores: RIC 2476/2012, PDC 1490/2014, REQ 3935/2016. Sustam a aplicação da decisão do julgamento da ADPF 54: PDC 565/2012, PDC 566/2012. Sobre complementação alimentar com ácido fólico para prevenir a anencefalia: PL 3933/2008, PL 1683/2007, PL 6879/2010, INC 3118/2012, PL 5666/2013, PL 232/2015. Projetos pró-escolha sobre anencefalia: PL 4304/2004, PL 4360/2004, PL 4403/2004, PL 4834/2005, PL 660/2007.

13 Cf. (Matoso, 2014). O deputado católico André Moura (PSC-SE) criou o PDC 1490/2014 a fim de revogar a portaria. 
BOURDIEU, P. A crença e o corpo. In: BOURDIEU, P. O senso prático. Petrópolis: Vozes, 2011. p. 108-132.

BRASIL. Presidência da República. Casa Civil. Subchefia para Assuntos Jurídicos. Decreto-lei $n^{\circ}$ 2.848, de 7 de dezembro de 1940. Rio de Janeiro, 1940. Disponível em: <http://www.planalto.gov.br/ccivil_03/decreto-lei/Del2848compilado.htm>. Acesso em: 26 set. 2017.

BRASIL. Supremo Tribunal Federal. Petição inicial referente à Arguição de Descumprimento de Preceito Fundamental (ADPF) 54. Brasília, 2004.

BRASIL. Ministério da Saúde. Secretaria de Atenção à Saúde. Portaria nº 415, de 21 de maio de 2014. Inclui o procedimento interrupção da gestação/antecipação terapêutica do parto previstas em lei e todos os seus atributos na Tabela de Procedimentos, Medicamentos, Órteses/Próteses e Materiais Especiais do SUS. Brasília, 2014. Disponível em: <http://bvsms.saude.gov.br/bvs/saudelegis/sas/2014/prt0415_21_05_2014. html>. Acesso em: 26 set. 2017.

CASANOVA, J. Public religions in the modern world. Chicago. University of Chicago Press, 1994.

CASANOVA, J. A globalização do catolicismo e o retorno a uma Igreja Universal. Revista de Estudos da Religião, ano 10, p. 17-45, dez. 2010.

CONFERÊNCIA NACIONAL DOS BISPOS DO BRASIL. CNBB convoca para Vigília de Oração pela Vida. 7 abr. 2012. Disponível em: <http://www.cnbb.org.br/site/imprensa/ noticias/9005-cnbb-convoca-para-vigilia-de-oracao-pela-vida>. Acesso em: 4 set. 2013.

CUNHA, A. L. S. da. Pessoa e direito, corpo e ciência: negociando significados e preceitos cosmológicos em torno da legalização do aborto. 2007. Dissertação (Mestrado em Antropologia Social)-Universidade de Brasília, Brasília, 2007.

DUMONT, L. Homo hierarchicus: o sistema de castas e suas implicações. São Paulo: Edusp, 1997.

DURKHEIM, E. L'individualisme et les intellectuels. In: DURKHEIM, E. La science sociale et l'action. Paris: Presses Universitaires de France, 1970. p. 261-278.

DURKHEIM, E. As formas elementares da vida religiosa. São Paulo: Paulinas, 1989.

DWORKIN, R. Domínio da vida: aborto, eutanásia e liberdades individuais. São Paulo: Martins Fontes, 2003.

FERNANDES, M. C. Interrupção de gravidez de feto anencefálico: uma análise constitucional. In: SARMENTO, D.; PIOVESAN, F. (Org.). Nos limites da vida: aborto, clonagem humana, eutanásia sob a perspectiva dos direitos humanos. Rio de Janeiro: Lumen Juris, 2007. p. 111-158. 
FONSECA, C.; CARDARELLO, A. Direitos dos mais e menos humanos. Horizontes Antropológicos, Porto Alegre, ano 5, n. 10, p. 83-121, maio 1999.

FRANKLIN, S. Life. In: REICH, W. (Ed.). Encyclopedia of bioethics. New York: MacMillan, 1995. p. 1345-1351.

FREIRE, A. Cabral defende aborto contra violência no Rio de Janeiro. G1, 24 out. 2007. Disponível em: <http://gl.globo.com/Noticias/Politica/0,,MUL155710-5601,00-CAB $\mathrm{RAL}+\mathrm{DEFENDE}+\mathrm{ABORTO}+\mathrm{CONTRA}+\mathrm{VIOLENCIA}+\mathrm{NO}+\mathrm{RIO}+\mathrm{DE}+\mathrm{JANEIRO} \cdot \mathrm{html}>$. Acesso em: 26 set. 2017.

LUNA, N. Fetos anencefálicos e embriões para pesquisa: sujeitos de direitos?. Revista Estudos Feministas, Florianópolis, v. 17, n. 2, p. 307-333, 2009.

LUNA, N. O direito à vida no contexto do aborto e da pesquisa com células-tronco embrionárias: disputas de agentes e valores religiosos em um Estado laico. Religião e Sociedade, Rio de Janeiro, v. 33, n. 1, p. 71-97, 2013.

LUNA, N. Aborto e corporalidade: sofrimento e violência nas disputas morais através de imagens. Horizontes Antropológicos, Porto Alegre, ano 20, n. 42, p. 293-325, jun./ dez. 2014.

LUNA, N. From abortion to embryonic stem cell research: biossociality and the constitution of subjects in the debate over human rights. Vibrant, v. 12, n. 1, p. 167-203, June 2015.

MARTINS, D. Pastor e deputado Marco Feliciano convoca cristãos para Vigília no STF. Dom Luiz Bergonzini, 7 abr. 2012. Disponível em: <http://www.domluizbergonzini.com.br/2012/04/pastor-e-deputado-marco-feliciano.html>. Acesso em: 5 jul. 2013.

MATOSO, F. Ministério revoga portaria que incluiu aborto legal na tabela do SUS. G1. Bem Estar, 30 maio 2014. Disponível em: <http://g1.globo.com/bemestar/noticia/2014/05/ministerio-revoga-portaria-que-incluiu-aborto-legal-na-tabela-do-sus. html>. Acesso em: 26 set. 2017.

MONTERO, P. "Religiões públicas” ou religiões na esfera pública? Para uma crítica ao conceito de campo religioso de Pierre Bourdieu. Religião e Sociedade, Rio de Janeiro, v. 36, n. 1, p. 128-150, 2016.

MONTERO, P.; BRUM, A.; QUINTANILHA, R. Ritos católicos e ritos civis: a configuração da fala pública da Igreja Católica em dois atos em memória de Vladimir Herzog (1975/2015). Mana, Rio de Janeiro, v. 22, n. 3, p. 705-735, dez. 2016.

QUEM é Santa Gianna Beretta?. Canção Nova, 15 ago. 2014. Disponível em: <https:// eventos.cancaonova.com/cobertura/quem-e-santa-gianna-beretta-2/>. Acesso em: 26 set. 2017. 
SANCHIS, P. O repto pentecostal à cultura católico-brasileira. In: ANTONIAZZI, A. et al. Nem anjos nem demônios: interpretações sociológicas do pentecostalismo. Petrópolis: Vozes, 1994, p. 34-63.

TURNER, V. Floresta de símbolos: aspectos do ritual ndembu. Niterói: Eduff, 2003.

VAGGIONE, J. M. La “cultura de la vida”: desplazamientos estratégicos del activismo católico conservador frente a los derechos sexuales y reproductivos. Religião e Sociedade, Rio de Janeiro, v. 32, n. 2, p. 57-80, 2012.

Recebido: 30/09/2017 Aceito: 11/05/2018 | Received: 9/30/2017 Accepted: 5/11/2018 